\title{
MATTHEW BURROW RAY
}

Dr. Matthew B. Ray died at an advanced age on July 5 in a London nursing home. He graduated M.B., C.M., in the University of Edinburgh in 1893 and proceeded M.D. in 1903; in 1934 he took the M.R.C.P. examination. With his death there also passed away yet another of those few remaining ties with the period when a "good physician" earned this title because there was something born and bred in him quite incapable of being acquired. This inner fire never glowed more brightly than in Dr. Ray's last illness, when the gallant courage with which he fought his infection won his doctor's admiration.

So through all his life, quiet, intense, loyal application to the work that was his duty at the time has been the keynote of his character. These traits were seen during the first world war when he won the D.S.O., and was A.D.M.S. of his division with the rank of Colonel. They appeared again when he was quietly hammering with the late Dr. Fortescue Fox at the doors of the British Red Cross Society to give a lead in the treatment of rheumatism and arthritis in London.

The fruit of these endeavours is known and respected throughout the world as the Arthur Stanley Institute for the Rheumatic Diseases, now an integral part of the Middlesex Hospital. Dr. Ray was the senior of the five physicians that constituted the original honorary staff, and after the Institute (then known as the British Red Cross Society Clinic) had become an established entity, he became the first chairman of their honorary medical committee. In recognition of his services in the foundation and development of the Institute, the governing body of the British Red Cross Society passed a special resolution that he should remain a member of the full active staff as long as he so wished. It would have been his wish to have served the Institute to the end, but this was not to be. The coming of the Health Acts brought about the absorption of the Clinic into the nearby Middlesex Hospital, and entailed the cancellation of this recognition. Dr. Ray was therefore transferred to the Consulting Staff, but he continued to attend the Marylebone Dispensary with the same remarkable regularity and loyalty that he had shown throughout the twenty years of his association with the Clinic and Institute.

Dr. Ray's knowledge of hydrotherapy and of spas at home and abroad was most extensive, and when his help in selecting a suitable technique or place of treatment was sought, this knowledge was readily and helpfully given.

Besides his sound clinical ability, and the great devotion apparent in his medical work, Ray had two important hobbies: painting and carpentry. He exhibited regularly in the annual exhibitions of the Medical Art Society and was a skilled cabinet-maker. It is perhaps not insignificant that in his steadfastness and simplicity of character he combined the calling of physician and healer with a practical skill in carpentry, thus following in the steps of the Great Healer as he went about doing good.

C. B. Heald. 